\title{
$-1-$ \\ MEDIEVAL NOVGOROD IN ITS WIDER CONTEXT
}

\author{
M. A. Brisbane, N. A. Makarov and E. N. Nosov
}

\section{BACKGROUND}

As is well known, the depth and extent of the preservation of Novgorod's waterlogged habitation levels from the 10th to 15th centuries is a unique phenomenon in the urban archaeology of Europe. It is therefore not surprising that modern excavations, which began in 1932, have taken place annually since, only being interrupted during World War II. It is only natural that the rich materials obtained from these excavations should have attracted the attention of scholars from far and wide, who have devoted dozens of monographs and articles to Novgorod (see for instance the comprehensive Novgorod bibliographies compiled by Gaidukov 1992; 2006; 2007).

However, the city did not exist in isolation. It was linked to its environs by thousands of different threads and could not have survived without that hinterland. From those rural areas food for people, fodder for livestock, raw materials for various types of production, building materials and manufactured items all flowed into Novgorod. The city in its turn supplied the rural population with diverse items, some fashioned by its craftsmen and others imported from further afield.

For many years scholars' attention has been largely focused on the study of the eye-catching materials discovered within the city. Rather surprisingly, analyses of the relationship between town and country and comparisons between various kinds of rural settlements against the background of the city's culture had not been undertaken. For example, until work on the INTAS projects began in the mid-1990s, inadequate attention had been paid to faunal assemblages, plant macrofossils, pollen and other data that can monitor local and regional environmental conditions, agriculture and the economy. These analyses, and in particular, comparisons between the city and its wider territory, represent key tasks for today's scholars engaged in the study of Novgorod and were to become one of the main foci of the INTAS projects represented by the reports and papers contained within this volume.

There were two main types of rural territories linked with the city. First, those in its immediate vicinity, notably the area adjacent to Lake Ilmen and in particular the area known as Poozerie (see Figure 1.1), a narrow strip of fertile land to the northwest of the lake, which had been densely populated since at least the late 7th or early 8th century. Some of the numerous settlements in Poozerie have been excavated and their materials analysed (Nosov 1992; 2001). It was the population of this area which we know supplied Novgorod with foodstuffs. A late medieval example of this can be 


\section{A. BRISBANE, N. A. MAKAROV AND E. N. NOSOV}

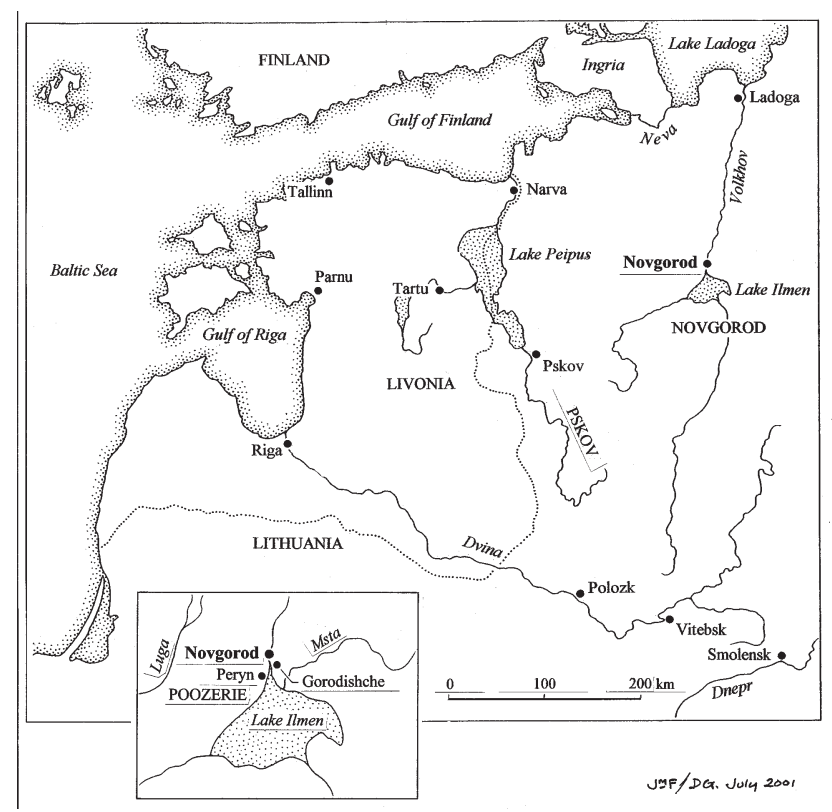

Figure 1.1 Map showing location of Novgorod and Ryurik Gorodishche with the area of early medieval settlement known as Poozerie along the north-west edge of Lake Ilmen. Drawn by John Hodgson.

seen in the land registers of the Shelon pyatina (a former administrative subdivision) of Novgorod dating from 1498 to 1503, where we see that eight cabbages, 80 turnips, 20 brooms and two bundles of green vegetables were sent regularly each week from the village of Rakoma in Poozerie to the governors employed by the Grand Prince at Ryurik Gorodishche (the former seat of the Prince). The same range of products would also be sent to the dvoretskii or chamberlain in charge of the palace household and to the tiun or judge. Furthermore, the chamberlain could also count on some sheep and a pile of firewood $80 \mathrm{~m}$ long to see him through the winter. It is clear that similar deliveries must have been made earlier as well, but we do not have any information of this from written sources. Other rural settlements around the shores of Lake Ilmen would also have had similar close links to the city of Novgorod.

Secondly, there were the rural territories that lay at some distance from the city and which together comprised the so-called Novgorod Lands (Figure 1.2). These lands made up a huge territory controlled and exploited by Novgorod, although it would be wrong to see this as a unified political entity (see for instance Halperin 1999). At their greatest extent from the 12th to 15th century, they stretched from the Baltic to the Urals and covered an area approximately the size of present day France, Belgium and the Netherlands combined.

The evolution and structure of rural settlements further away from Novgorod and the other main centres of northern and north-eastern Russia differed in certain respects 


\section{MEDIEVAL NOVGOROD IN ITS WIDER CONTEXT}

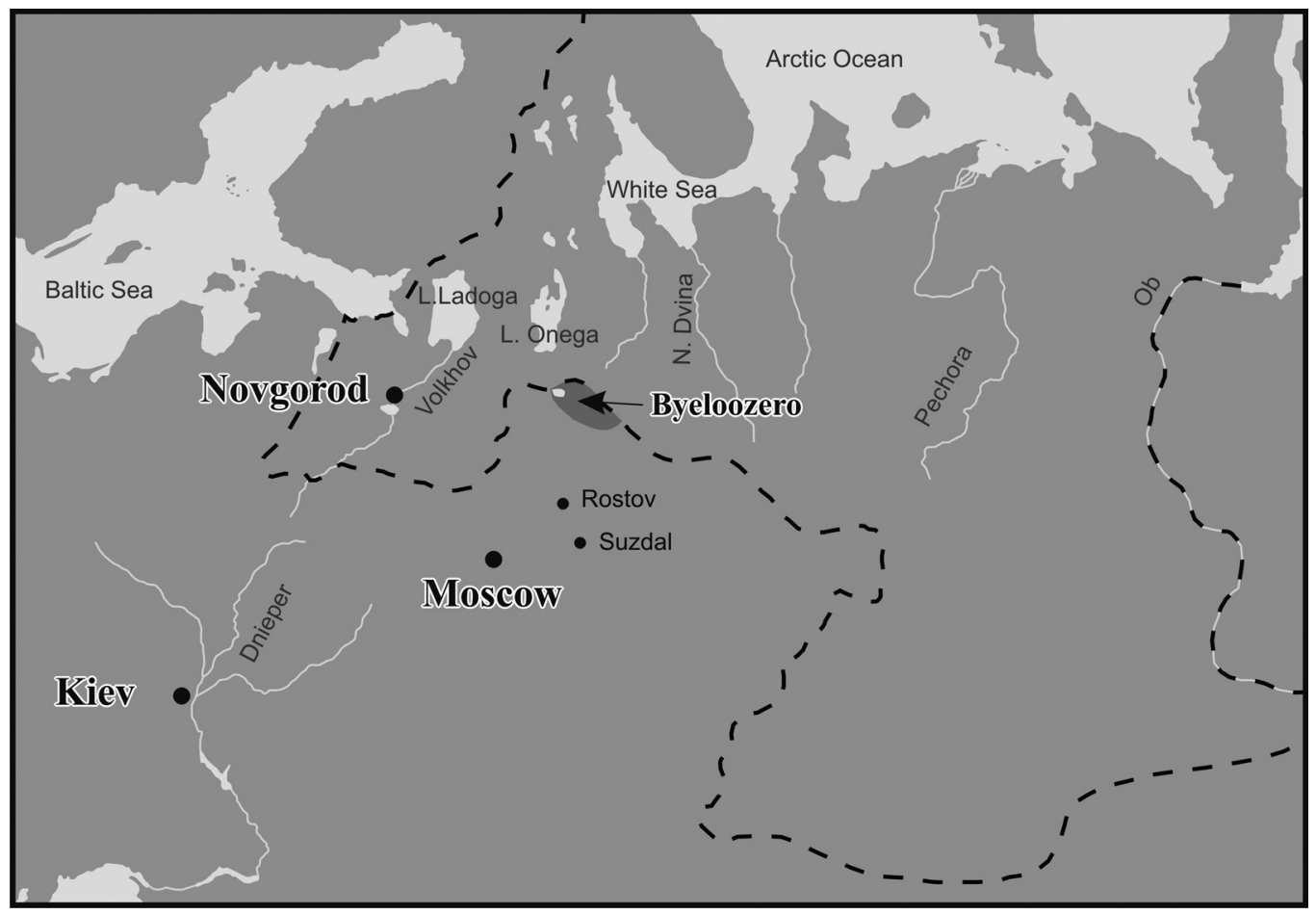

Figure 1.2 Map of Novgorod Land around AD 1400. After Yanin 1990, 74. Redrawn by Mark Dover.

from those in the immediate vicinity of the city. These differences can be observed in relation to their economic development, the role of crafts, agriculture, trade, hunting, fishing and various other activities. Nevertheless, the wide-ranging and detailed study of medieval sites such as the settlements at Minino on Lake Kubenskoye, together with the analysis of materials from Novgorod's immediate environs and Novgorod itself, help us to understand the historical and cultural processes at work within the northern part of the medieval Russian state at various stages of its history.

Many of the papers in this volume have been produced as part of a project that aimed to draw out some of the details that contribute to an understanding of first, the relationships between the centre, its hinterland and its periphery, and second the various types of activities that took place in each of these locations.

\section{THE STUDY OF NOVGOROD AND NOVGOROD LAND}

Medieval Novgorod was the centre of an enormous territory with a complex economy, whose prosperity and political might were made possible by the city's control over 


\section{A. BRISBANE, N. A. MAKAROV AND E. N. NOSOV}

far-flung lands in the northern part of European Russia, which stretched from the Gulf of Finland to the Northern Urals. It is impossible to uncover the history of the emergence of Novgorod without investigating its rural hinterland, which provided the foundation for the city's development and the formation and expansion of the Novgorod Lands, the natural resources at the disposal of the Novgorod population, and the actual methods for the exploitation of those resources, which made wealth creation possible.

Archaeological discoveries in Novgorod have lent powerful momentum to the study of the historical geography of these Novgorod Lands and the way they were administered, to research into aspects of the medieval colonization of north-western Russia, and into rural patterns of settlement in its various regions.

During the last 15 years or so, archaeological investigations in and around Novgorod have increased interest in the environmental context of Novgorod's development and the key rural regions of northern Russia. As research in these directions has advanced, it has emerged that the interconnections between medieval Novgorod, the rural territories of the Novgorod Lands and the natural resources of the North as factors in the growth of the medieval economy and of the prosperity of the Novgorod boyars were both complicated and far-reaching. The task of this volume has not been to provide a comprehensive picture of Novgorod as the organizing force behind the economy of the North, nor was it intended to produce a definitive account of agricultural and craft production and the circulation of these products by the population of the territories under Novgorod's control. Rather its main aim is to acquaint the reader with some of the important results of recent archaeological and palaeo-environmental research, which are beginning to provide new insights into certain aspects of these topics.

\section{The growth and structure of Novgorod Land}

The general geographical extent of the Novgorod Lands in the 12th-13th centuries was established in the studies by Nasonov and Kuza on the basis of information provided in the chronicles and legal documents. These include agreements concluded between the veche (popular assembly) of Novgorod and its princes, the earliest of which dates from 1264 (Nasonov 1951, 69-117; Kuza 1975, 144-201). It has long been established by scholars that the enormous Novgorod Lands included the main area nearer to Novgorod itself with a system of rural parishes (pogost) - administrative centres responsible for tax collection - and volosts, which were separate administrative units on the fringes of the Novgorod Lands that enjoyed special legal status, but who nevertheless paid tribute, mostly in furs, to Novgorod.

Initially, the nucleus of the Novgorod Lands had been relatively modest in size and was confined mainly to the territory around Lake Ilmen and along the River Volkhov. As suggested by Yanin, it was not until the middle of the 10th century that territory around the floodplains of the River Luga and the River Msta (which flows into Lake Ilmen), areas that contained large clusters of medieval settlements, came under Novgorod's control. He dates their incorporation into the Novgorod Lands 


\section{MEDIEVAL NOVGOROD IN ITS WIDER CONTEXT}

to the year 947, when, according to the chronicles, Princess Olga "gave orders for pogosts and tax collection" to be introduced along the Msta and Luga Rivers (Yanin 2004, 129). The outline of the earliest core of the Novgorod Lands in the area around Lake Ilmen and the gradual expansion of the Novgorod domain into the Ilmen Basin and the upper reaches of the Volga in the 10th and 11th centuries has been examined in detail by Nosov (Nosov 1992, 15-35; Nosov et al. 2005, 5-7). He and his team have identified a high concentration of medieval settlements in Poozerie (an area adjacent to Lake Ilmen, SW of Novgorod), which reflects the special role of that territory during the rise of Northern Russia in the medieval period.

However, written sources on the territorial expansion of the Novgorod Lands and their administrative structures in the 11th-13th centuries are extremely meagre. This is why the discovery of birch-bark documents within the Novgorod excavations is so significant in the archaeological study of medieval Russia, for their texts not only contain the names of geographical locations but also the names of volosts and centres of population in various parts of the Ilmen Basin and the upper reaches of the Volga (Rybina 1993, 344-347; Yanin 2001, 66-67; 2004, 110-113). For instance, some of the birch-bark documents contain lists of payments and interest in connection with money-lending coming in from the regions bordering on the Rivers Luga and Shelon and Lake Seliger (BBD No. 526, second third of the 11th century), payments received from the Shidovitskii parish in the valley of the River Tvertsa and the village of Lama on the River Volchina, a tributary of the Mologa (BBD No. 789, last quarter of the 11th century), payments from the village of Ezsk on the River Mologa and the volost of Volchina (BBD No. 902, late 11th or early 12th century), the distribution of land possessions beyond the River Msta (BBD No. 724, 1160s), the inhabitants of the Imovolozhe and Zhabna pogosts and the village of Mlevo on the River Msta (BD No. 885 , mid-12th century).

In addition to the birchbark documents, wooden cylindrical seals have been discovered in Novgorod bearing inscriptions containing the names of rural parishes of the 11th-12th centuries in the basin of the Onega and Northern Dvina Rivers, on the far north-eastern fringe of the Novgorod Lands (Yanin 1982, 138-157; 2001, 68-82; $2004,101-110)$. Also on cylinders dating from the 11th and first quarter of the 12th century, we find the names "Tikhmega" (the parish of Tikhmanga on Lake Lacha in the basin of the Onega River), "Vaga" and "Ust-Vaga" (taxation districts on the River Vaga, a southern tributary of the Northern Dvina), and "Emtsa" (a taxation district on the river Emtsa, a southern tributary of the Northern Dvina river) (Yanin 2004, 101-110; Makarov 2003, 149-163).

Yanin has convincingly argued that these wooden cylinders were locks from sacks, in which furs were brought to Novgorod. These had been collected as tribute in the northern regions, such as Zavolochie. Inscriptions on the cylinders designated the taxation district, in which the valuable furs had been collected. Birch-bark documents and wooden cylinders of the 11th and 12th centuries bearing names of taxation districts and pogosts are therefore vitally important, not only for providing a detailed picture of medieval settlement patterns and administrative arrangements, but also as convincing 


\section{A. BRISBANE, N. A. MAKAROV AND E. N. NOSOV}

evidence of the presence of a Novgorod administration within extensive areas of the North. They confirm that Novgorod had, indeed, been receiving "resources from the periphery", i.e. tribute and payments from the upper reaches of the Volga, the valleys of the Luga and Msta rivers and pogosts in Zavolochie.

\section{Rivals to Novgorod: the growth of Rostov-Suzdal}

Novgorod was not the only centre endeavouring to spread its power and influence within the northern expanses of north-eastern Europe at this time. Its rivals in the colonization of the North were the urban centres of the Rostov-Suzdal Lands, which lay to the east of Novgorod and its territory. These had extended their influence from the Volga-Klyazma interfluve to as far as the east bank of the Volga, the River Sheksna, the lake known as Byeloe Ozero (literally White Lake), the Northern Dvina river and to its southern tributary, the Vaga (Nasonov 1951, 188-197; Kuchkin 1984, 55-104). The outposts of the colonisation outwards from the Rostov-Suzdal Lands were the town of Byeloozero, the fortress of Gleden built in 1178, the town of Velikii Ustyug founded in 1212, and the settlements near the source of the Northern Dvina. Byeloozero, on the south shore of Byeloe Ozero, is mentioned in the chronicles and is one of the earliest Russian towns in the area with settlement evidence dating from the second half of the 10th century (Makarov et al 2001).

Northern boundary disputes between Rostov-Suzdal possessions and those of Novgorod were accompanied by fierce armed conflicts, which were first mentioned in the chronicles in the year 1169, when Novgorod forces defeated tribute collectors from Suzdal and seized what they had collected from territories under the jurisdiction of the Suzdal princes. The military rivalry between Novgorod and the Vladimir-Suzdal princes in the late-12th and early-13th centuries has been examined by historians, who have made exhaustive searches of the written sources, which unfortunately are far from extensive (Nasonov 1951, 188-197; Kuchkin 1984, 89-103). An important supplement to the chronicles is provided by Novgorod birch-bark document No. 724 sent from the North to Novgorod. This contains a report from a certain Sava, leader of Novgorod tribute-collectors, which tells of his own unsuccessful attempt to collect furs but that "our man Andrei" (a representative of Andrei Yurievich Bogolyubskii, Prince of Vladimir) had obtained the tribute (Yanin 1993, 114-119). With reference to archaeological materials, it can be assumed that the beginning of the rivalry in the North between Novgorod and the rulers of Rostov and Suzdal dates from the 10th century, when men from Novgorod made their way as far as Byeloe Ozero and the Sheksna river from the West, and settlers from Rostov came up from the South, moving up the Sheksna river (Makarov 1989; 1997, 166-168). The fact that there existed lands under the jurisdiction of Novgorod on the one hand, and under that of Rostov and Suzdal on the other, on the 'wrong' side of the demarcation line in the valley of the River Sukhon and in the basin of the Vaga reflects the complicated nature of this long struggle, the details of which do not find their way into the pages of the chronicles. 


\section{MEDIEVAL NOVGOROD IN ITS WIDER CONTEXT}

\section{Colonisation of the North}

Extensive archaeological surveys of rural areas in this northern region of north-eastern Europe in the close vicinity of medieval towns that formed the central core of large administrative units, but on the margins of the Novgorod and Rostov-Suzdal Lands, were embarked upon in the 1970s and then expanded in the 1990s. These surveys shed light on the nature of the cultural landscape and settlement patterns at the end of the first and beginning of the second millennium AD. This era is characterized by the emergence of a new network of settlements, which was not linked with the territorial units of the earlier period, extending over enormous expanses of land from the upper reaches of the River Dnieper and the River Volga to the area round Lake Ladoga and the Northern Dvina (Makarov et al. 2001, 217-226). The rapid growth in the number of rural settlements and the expansion of settled territories in these largely flat, wooded landscapes (where during previous millennia the concentration of people and exploitation of material resources had been extremely low) constituted a phenomenon of crucial importance in the medieval history of Eastern Europe in this period (probably no less significant than the beginning of urbanisation). The dynamics and intensity of colonization differed considerably from region to region, when new territories were being settled in the Russian north. Compact groups of rural settlements began taking shape usually near the water resources of large lakes and the valleys of large rivers interspersed by sparsely populated areas in the watersheds of river systems. Spore and pollen research shows that the emergence of new settlements was accompanied by the partial felling of forests, the laying out of fields, and the appearance of new agricultural crops. Despite specific features of rural colonization in all the different areas, it is clear that it began earlier in the north-west of Russia and developed more intensively there than in the north-east.

In view of the fact that the study of medieval settlement patterns in rural areas took the form of a number of separate regional projects and did not encompass the whole of the northern part of European Russia, it is impossible at the present time to piece together a general map of the main centres of rural settlement. In the north-west of Russia the territories that have been studied in the most detail are those around Lake Ilmen and along the River Volkhov. A small area of land stretching along the north-west shore of Lake Ilmen, which came to be known as (Ilmenskoye) Poozerie, is regarded by Nosov as one of the key areas of the wooded zone in eastern Europe. It is here that an extremely high concentration of rural settlements dating from the 9 th and 10th centuries has been recorded. As the most recent research has shown, the first medieval settlements in this territory took shape no later than the 8th century (Nosov 1991, 5-37; 1992, 5-65; Nosov et al. 2005, 122-154). The emergence of compact groups of medieval settlements in two other central parts of the Novgorod Lands, in the middle reaches of the Msta river and along the Luga river, evidently relates to a slightly later period, namely the 9th and 10th centuries (Nosov 1992, 23-25; Konetskii and Nosov 1995, 29-54; Platonova et al. 2007). At the end of the first millennium AD, centres with a high concentration of settlements also emerged in the central part of 


\section{A. BRISBANE, N. A. MAKAROV AND E. N. NOSOV}

the future Rostov-Suzdal Lands, that is, in the Volga-Klyazma interfluve near Lake Nero (near the town of Rostov) and Lake Pleshcheevo, and in the Opolie region near Suzdal (Leontiev 1996, 19-66; Makarov et al. 2005, 196-215). At that time there also existed large and stable clusters of settlements in the Mologa-Suda interfluve (Bashenkin 1995, 3-28). However, in large areas of the North there are only isolated traces of 9 th/10th-century settlements or none at all. Colonization was pursued on a significantly wider scale in the 11th and 12th centuries, predominantly in an easterly and north-easterly direction. During this period the network of rural settlements in areas already long settled became denser and more compact (Makarov et al. 2005, 196-215), while in the margins of the Novgorod and Rostov-Suzdal Lands newly populated rural areas were emerging.

For an understanding of the history of the colonization of the northern margins of medieval Russia, the results of many years' research into the settlements on the shores of the Byeloe Ozero and Lake Kubenskoye are highly relevant. Scholars have attempted to identify and map all the settlements in those areas dating from the 11th to the 13th century. In the basin of the first of those two lakes (a large expanse of water, from which rises the River Sheksna, one of the eastern tributaries of the Volga), some 170 large medieval villages have been identified within an area of approximately $9,000 \mathrm{~km}^{2}$. Most of these settlements were not large and they occupied low terraces near large rivers and lakes and they tended to be grouped together in clusters. The network of 9th- and 10th-century settlements around Byeloe Ozero was sparse: the real growth in their number began in the 11th century and accelerated in the early 12th and 13th century. Some settlements were situated at portages linking the water systems of the Volga, the Northern Dvina and Onega rivers and Lake Onega. It was not until the 14th century that watershed areas began to be settled. In the second half of the 13th century the network of settlements underwent a major transformation reflected in the partial abandonment of settlements, which had come into being in the 10th to 13th centuries, and a spread of colonization to higher ground within the watersheds (Makarov et al. 2001). Colonization developed in a similar way in the area around Lake Kubenskoye to the east of Byeloe Ozero, in which the River Sukhon rises. Around that lake, which has a total area of approximately $370 \mathrm{~km}^{2}, 16$ settlements dating from the 10th to the 13th centuries have been identified: most of which were small and situated near the mouths of rivers flowing into the lake (Makarov 2007, 43-62). The system of settlements which took shape in that period on the shores of Byeloe Ozero and Lake Kubenskoye provided convenient links for the major urban centres of both north-western and north-eastern Russia, providing access to the main products and resources of the North. Although the territories around Byeloe Ozero and Lake Kubenskoye were part of the Rostov-Suzdal Lands, a large proportion of the artefact collections dating from the 10th to 13th centuries are objects of a northwestern type, reflecting their close cultural and commercial links with Novgorod and the Baltic region (see also Makarov 2009).

When scholars turned their attention to archaeological materials, which were being 


\section{MEDIEVAL NOVGOROD IN ITS WIDER CONTEXT}

collected from excavations of northern Russian settlements, and which characterized the culture, production and consumption to be found in rural settlements, they were obliged to reconsider many stereotypes in the assessment of rural society in medieval Russia of the 10th-13th centuries, which had taken shape in historical writing. Archaeological sources testify to high levels of prosperity in rural society, to its involvement in commerce and to the complex organization underlying the economy of rural settlements, in which trades and crafts played an important part. In addition, they showed that a large proportion of the household articles and jewellery found in the towns was also accessible to the rural population. Equally surprising were finds of high-status articles and imports, which are common from many rural sites, although the variety and abundance of such articles can vary considerably from one settlement to another. Researchers are aware that they will soon have at their disposal increasing amounts of such material, demonstrating that the cultural and economic differences between the towns and villages of medieval northern Russia did not run nearly as deep as has been believed up till now. It is worth stressing again how these findings run counter to existing historical explanations and narratives.

\section{CONCLUSIONS}

It can thus be seen that the growth of Novgorod and the consolidation of its role as an economic and political centre in the 10th to 13th centuries took place at a time when rural areas were being colonized on a wide scale. The power of the Novgorod elite made itself felt through large parts of the North and an extensive exchange of commodities between Novgorod and rural settlements was taking place, as is testified by finds of numerous imports and articles made by urban craftsmen in the rural settlements. In order to shed light on the actual connection between the advance of Novgorod, the colonization of rural areas and the emergence of mechanisms for incorporating the agricultural products and resources from the northern areas of eastern Europe into the broader system of international trade, new forms of data were required. These needed to characterize the following: the palaeo-environment of medieval settlements; the settlement of rural areas in both the central and peripheral parts of the Novgorod Lands; the economy and patterns of consumption in medieval settlements; and the resources and raw materials used by the actual inhabitants of Novgorod. Studies of a wide range of materials presented in this volume include articles that collectively shed light on all of these topics. 